\title{
Education is the Best Contraceptive: A Case Study of Faisalabad
}

\author{
Khalique Kamboh \\ Lecturer in Geography University Community College Faisalabad, Pakistan \\ Email:mkh_kamboh@yahoo.com \\ Ayesha Saleem \\ Lecturer/coordinator in Geography Government College University, Faisalabad, Pakistan \\ Email: ayeshageographr@gmail.com \\ Imran Muslim \\ Lecturer in Mass Communication, University Community College, Faisalabad \\ Sibqat Ullah Tahir \\ Associate professor/principal, Govt. Community College, \\ Govt College University Faisalabad \\ Sibqat@yahoo.com
}

\section{Doi:10.5901/jesr.2014.v4n3p475}

\begin{abstract}
The study examined the role of education on fertility trends in Faisalabad city. For the purpose primary and secondary sources of data were used. Primary data was collected through structured questionnaire and total sample of 250 respondents was selected from four locations of Faisalabad city. Level of education, ideal family size and wife s' education were variables for the purpose. It was observed that education has a great effect on number of children, ideal family size. Family size is directly related to education level of the mother.
\end{abstract}

Keywords: fertility, education, family size, literacy

\section{Introduction}

The main purpose of this paper is to examine the role of education on fertility rate in Faisalabad. The education of female has a great influence on number of children she has (Trewartha, 1953). Although, role played by female education is very helpful in slowing down population growth. A macro to micro level study of fertility and its relation with education may be a diverse initiative in the study (Henz, U. 2008). Widespread fertility declines accompanied by increases in educational attainment level have occurred in most Western countries. In all European countries, the actual number of children remains below the desired number of children (Goldstein, 2003). Pakistan's overall condition cannot be separated from the rest of the world. The rate of growth in Pakistan is highest among eight largest countries. This suggests that the whole story is about the fertility behavior at the family level (BUTT, S.M., et al, 1993). In Pakistan the level of education is highly affecting the fertility trends. In rural areas where less educated people are living (TOOR, I. A. 2007). A case study comparison of fertility on the bases of educational level to look into the fertility differentials, whether education affects fertility or not and if it to what extent and what kind of relationship exists between the variables. Many researches emphasized the fact that education has direct relation with number of children in family like but on the other side of the coin the researchers like Rossier (2008) and Kreyenfeld (2003) suggests that there is no positive relationship between the two parameters.

\section{Methodology}

Both primary and secondary data were collected. The following variables for the cohorts were considered for the study; 
male education, female education, planning, ideal family size, Stratified sampling technique was used for the survey was purely based on selective levels of literacy. However areas were selected on the socio-economic bases.

Following four areas of Faisalabad are selected for the survey,

1. Warris Pura

2. Peoples Colony

3. Gulstan Colony

4. Ghulam Muhammad Abad

Almost 250 married males are interviewed in each location. Five subgroups are made as the stratified method was used.

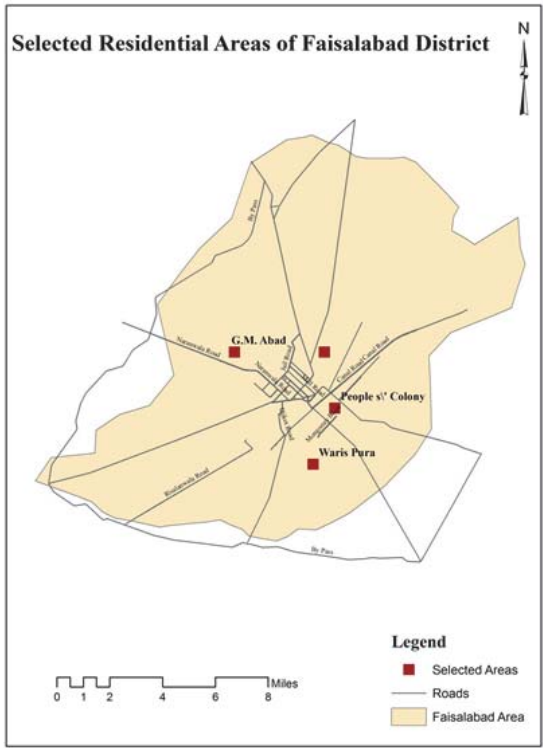

\section{Results and Discussions}

Table 1.1: Education level and no. Of children per family

\begin{tabular}{|l|c|}
\hline Education level & No. of children per family \\
\hline Illiterate & 6.2 \\
\hline Literate & 5.7 \\
\hline 10 year of education & 4.52 \\
\hline 14 year of education & 3.167 \\
\hline 16 year of education & 3.05 \\
\hline
\end{tabular}

Source: Author, 2013

Ideal family size was the question which has again suggested the respondents by education. No idea or the will of God was the answer by most of the illiterate respondents having 10 years of education. Some respondents exactly tell the actual number of their children as the ideal family size. Whereas most of the respondents aspired less family size than their actual one. Four to seven was the number of children as ideal family size by the respondents of illiterate class. Wide variations are found in literate respondent which is three to seven children as their ideal family size. Respondents with 10 years of education idealized the family. Whereas respondent with 14 years of education and 16 years and above education aspired two to four children as their ideal family size. Family size of three is the most frequent answers by both these levels of education with a figure of $61 \%$ and $56 \%$ of the both classes respectively. 
Table 1.2: Service status of respondent's wife by their education and mean number of children.

\begin{tabular}{|l|c|c|c|c|c|}
\hline Service status & Illiterate & Literate & 10 years & 14 years & 16 years \\
\hline Self employed & 6.1 & 5.8 & 3.2 & 2.4 & 2.1 \\
\hline Private service & 4.8 & 4.7 & 3.0 & 2.2 & 1.8 \\
\hline Govt. service & 4.6 & 4.2 & 3.1 & 2.3 & 1.9 \\
\hline
\end{tabular}

Source: Author, 2011

However the survey was not focused on the women as respondents however a result compiled regarding the service status of respondents wives. This figure shows that compare to house wives women in service have much less average family size, and educated women especially in service have much lesser number of average family size. Self-employed illiterate women have 6.1 average family size, whereas illiterate women in Govt. service have 4.6 average family size.

Figure 1.2: Percentage of respondents by education level and ideal family size.

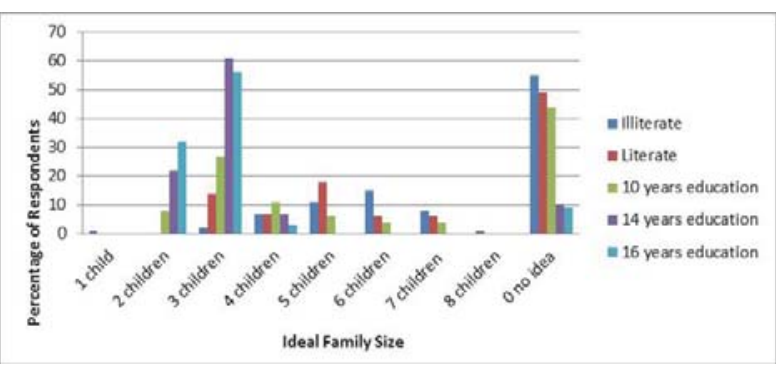

Source: Author, 2011

Ideal family size was the question which has again suggested the respondents by education. No idea or the will of God was the answer by most of the illiterate respondents having 10 years of education. Some respondents exactly tell the actual number of their children as the ideal family size. Whereas most of the respondents aspired less family size than their actual one. Four to seven was the number of children as ideal family size by the respondents of illiterate class. Wide variations are found in literate respondent which is three to seven children as their ideal family size. Respondents with 10 years of education idealized the family. Whereas respondent with 14 years of education and 16 years and above education aspired two to four children as their ideal family size. Family size of three is the most frequent answers by both these levels of education with a figure of $61 \%$ and $56 \%$ of the both classes respectively.

\section{References}

Trewartha, G. T. 1953. A Case for Population Geography, In Population Geography: A Reader, George Demko, etal,(1970) New York, McGraw-Hill.

Henz, U. 2008. Gender roles and values of children: Childless couples in East and West Germany. Demographic Research 19(39): 1451-1500. doi:10.4054/DemRes.2008.19.39.

Goldstein, J., Lutz, W., Testa, M.R. 2003. The emergence of subreplacement family size ideals in Europe. Population Research and Policy Review 22(5-6): 479-496. doi:10.1023/B:POPU.0000020962.80895.4a.

Butt, S.M., et al, 1993 Determinant of Marital Fertility in Pakistan , Pakistan Development Review 32:2, Islamabad, Pakistan Institute of development Economics.

Toor, I. A. 2007. Returns To Education, The Case of Fertility, Pakistan Economic and Social Review, Volume 45, No. 1 (Summer 2007), pp. 107-123

Rossier, 2008. Family policy regimes in Europe and their relevance for the change of the family. An overview of the state of the art. Zeitschrift für Bevölkerungswissenschaft 1: 99-121.

Kreyenfeld, 2003. Family policy matters: Responding to family change in Europe. Bristol: The Policy Press. 
